\title{
Intermestic Factors of Indonesia's Halal Certification
}

\author{
Adkhilni Mudkhola Sidqi ${ }^{1}$, Akmal Salim Ruhana ${ }^{2}$ \\ \{amsidqi@kemlu.go.id ${ }^{1}$, akmalsalim@kemenag.go.id ${ }^{2}$ \} \\ Ministry of Foreign Affairs, Indonesia ${ }^{1}$, Ministry of Religious Affairs, Indonesia ${ }^{2}$
}

\begin{abstract}
The halal industry has become a thoughtful concern not only in Muslim countries but also the world. In Indonesia, the halal certification has been reinforced by Act number 33/2014 on halal guarantee products, which, among other things, requires all products to enter Indonesia to be halal certified. Several countries raised this mandatory halal certification at the World Trade Organization (WTO) sessions and Dispute Settlement Body Panel considering that as unnecessarily restrictive trade barriers. On the other hand, the implementation of the halal law is also constrained domestically. This paper discusses the interrelationship between the domestic and international dynamics of Indonesia's halal law enactment. This research using a qualitative approach collects data from literature reviews and online interviews with several authoritative parties both at home (government, parliament, halal NGO, and business associations) and abroad (Indonesian Embassies and halal certification bodies in European countries). By deploying an intermestic (international-domestic) approach, this research finds that the dynamic process of halal law implementation in Indonesia has a significant effect internationally. The international dynamic could also arguably jeopardize the implementation of halal law domestically. This study sees the intermestic factors of halal certification that need to be realized by domestic policy makers so that the halal guarantee products and certification run synergistically with domestic and international conditions.
\end{abstract}

Keywords: halal law, intermestic, WTO, international trade

\section{Introduction}

The potentials and opportunities in the future of the global halal industry are huge and promising. The Islamic economy - consisting of economic sectors whose core products and services are structurally affected by Islamic ethics and law - has established an increasingly important footing in the future global economy. The sectors are halal food, fashion, travel, cosmetics, pharmaceuticals, media and Islamic financial services. Global Muslim consumers spent US\$2.2 trillion in 2018, mostly in the food, pharmaceutical and lifestyle sectors. The number is expected to reach $\$ 3.2$ trillion by 2024 , while Islamic financial assets are forecasted to reach \$2.5 trillion in 2018 (Global Islamic Economic Report 2019/2020).

Today's global halal market is no longer confined to food and food-related products. With the increase in the number of affluent Muslims, the halal industry has expanded further into lifestyle offerings, including halal travel and hospitality services as well as fashion. This development has triggered by a revolutionary change in Muslim consumers mindset as well as ethical consumer trends worldwide.

Halal is not limited to OIC Countries or Islamic countries; thus, global governance on the halal industry is very crucial in creating understanding and cooperating with Muslims in Non- 
OIC Countries to regulate issues for them. In this regard, capacity building and training to better understand halal awareness, the probabilities of the halal market and future development will become essential steps in ensuring the development of global halal ecosystem and standards. It also presents the need for global cooperation on halal accreditation and certification in order to promote better international trade on halal products and services.

Indonesia, as a member of the OIC and the largest Muslim population country in the world, has excellent attention to the issue of halal. For a majority of Muslim consumers, Halal is an essential part of their daily lives as they strive to live according to the principles of Sharia law. In Indonesia, for instance, the level of intention to buy halal products among Indonesian Muslims reaches 70.1 per cent (Mulyono, 2018).[1]

In the past, Halal was mostly confined to food and food-related products. However, as the market rapidly grows, the Halal industry has expanded beyond food sectors, including pharmaceuticals, cosmetics, logistics, personal care and services such as financial and tourism. Since 1989, the Indonesian Council of Ulema (MUI) has overseen voluntary Halal certification and inspection.

In 2006, the Indonesian House of Representatives (DPR) began discussing the draft act on halal product guarantee. In September of 2014, DPR passed the first law, namely Act number 33 of the year 2014 concerning halal product guarantee. This new act is requiring mandatory Halal certification and labelling on a broad range of products, including 'goods and/or services that are related to foods, beverages, as well as consumer goods that are worn, used or utilized by the public' (Article 1 of the Halal Act). The Halal Act provides for a 5-year grace period for application, meaning that traders have until 2019 before the mandatory Halal labelling takes full effect.

Although Islamic organizations in Indonesia have welcomed the implementation of this legislation, local and foreign business entities, have expressed concerns as to whether such regulations will result in increased costs for them. (Limenta et al., 2017). The concern of new halal law in Indonesia has been raised in the World Trade Organization (WTO) sessions considering that new-fangled halal law as unnecessarily restrictive trade barriers. Additionally, international cooperation for accreditation and halal certification as stipulated in the act has been not an easy task to accomplish due to the diversity of Islamic standards and countries regulation conditions.[2]

The research question is: how significant is Indonesia's Halal Law interplay with international affairs? The answer is vital to describe Indonesia's Halal Law as a product of domestic politics that has a significant role in international affairs settings. This study also examines halal certification to be a decisive factor in Indonesia's foreign policy towards the primary consideration of international trade, business and religious issues.

\section{Theoretical Framework}

\subsection{Halal Multidimentions}

Halal is a word in Arabic that means lawful or allowed. Halal's opposite is haram, which means unlawful or forbidden. Halal and haram are commonly used in Islamic discourse concerning food products, meat products, cosmetics, pharmaceuticals, and food ingredients, as well as food contact materials. The word halal is mentioned in the Holy Quran, and so it is a religious term. Furthermore, there is a diverse understanding among Muslims in many 
countries regarding the measure of halalness. Each country had its fatwa (school of thought) and fiqh for halal standards, developed according to the beliefs of each society.

Halal certification or halal law is not only in the religious dimension but also in business and politics. Halal certification, for example, relates to the supply chain of domestic and foreign trade. Food producers will attempt to get a halal label because it will add value to the products they sell. As halal certification process is related to the export and import of goods, international cooperation will also be built. For example, there are efforts to build an understanding of mutual recognition of halal certification between two or more countries. In the Law No. 33/2014 re Halal Product Guarantee Law, for example, there is an opportunity for international cooperation called the Mutual Recognition Agreement on Halal Certificates.

\subsection{Indonesia's Halal Law}

As a state law (rechtsstaat), Indonesia regulates public affairs through the laws which are binding for all parties (Siallagan, 2016). The Halal Product Guarantee Act is a kind of accommodation for the aspiration of the most significant part of Indonesian people, who are Muslims. Once decided, this law applies and binds all parties at home and abroad. As this paper examines the influence of the Halal Product Guarantee Act on international affairs, both politics and trade, it is necessary to explain this law briefly. It is worth noting that this regulation is a political product of the Indonesian government, the result of serial discussions between the Government and Parliament. The draft of the bill was proposed in 2006 and decided in 2014 (Amaliah, 2016).[3]

Halal regulation in Indonesia has flowed into a new phase since the issuance of the Law No. 33 of 2014, or precisely since its enactment on 17 October 2019. If previously, halal certification and labelling were optional or voluntary, now it is mandatory. The Halal Product Guarantee Law, which was drafted in 2006 , for example, regulates that products that enter, circulate and are traded in Indonesian territory must be certified halal (article 4). Business sectors who have obtained a halal certificate are required to include a Halal Label on their products (articles 25 and 38). Likewise, those who produce products from non-halal goods must also include information that is not halal (article 26). There are tiered administrative sanctions for those who violate those provisions.

This law provides guidance for business actors to apply for halal certificates and other technical matters. There are derivative regulations, namely Government Regulation No. 31 of 2019 and Regulation of the Minister of Religious Affairs No. 26 of 2019. Unfortunately, the Ministry of Finance had not issued a regulation on certification rates yet. The absence of this regulation means that the certification process cannot be carried out thoroughly. Business actors have been very enthusiastic about applying for certification. Responding to this, the Minister of Religious Affairs then issued the Minister of Religious Affairs Decree No. 982 of 2019 which returns the process and its rates to the previous mechanism for certification, namely according to the rules imposed by the Assessment Institute for Foods, Drugs, and Cosmetics of the Indonesian Ulema Council (LPPOM MUI). Furthermore, the Omnibus Law Bill is currently being rolled out, which, to some extent, alludes to the Halal Product Guarantee Law.

In terms of international trade or, precisely, export and import activities, the prominent issue is that products that enter, circulate, and are traded in Indonesian territory should be certified halal (article 4). Apart from that, it is also stated that foreign halal products imported into Indonesia must comply with the provision as regulated in this law. i.e. certification process. Therefore, foreign companies who intend to market their products in Indonesia must 
first arrange the halal certificate for their products. However, for foreign companies who already have halal products do not require halal certificate application as long as the Halal Certificate issued by a foreign halal agency has performed a collaboration of recognition (article 47). They are only required to register their product before releasing to the market. In this regard, the crucial issue is, there has not been yet a Mutual Recognition Agreement (MRA) between the Indonesian government and any country. This means that the registration process cannot be carried out, but rather a halal certification.

\subsection{Intermestic Factor}

This paper opts for the linkage between domestic politics of Halal Law and international affairs. This method, described decades ago by Rosenau (1969) mentions that the studies of international politics would be advanced by examining more closely the linkage between domestic political systems and their implications for international affairs. Conventionally, specific ideas of domestic politics need to be recognized and embraced internally before projected abroad (Wolff and Wurm, 2011) to explain states' foreign policies more precisely (Fearon, 1998).[4],[5]

However, international politics also has a significant effect on its domestic sphere. As such, there is an interplay between international relations and the domestic sphere or called "intermestic" (international-domestic). The term "intermestic" originates from Manning (1979).

Manning (1979) suggests that certain foreign policies have such a powerful direct influence on the domestic sphere that the debates underlying them are embedded in international and domestic concerns. The word 'intermestic' derives from Manning (1979) that specific foreign policies have such a powerful direct influence on the domestic sphere that the debates are embedded in international and domestic concerns.[6]

Manning's original conception of intermestic affairs was mostly on international political economy and the domestic economy. Barilleaux (1985) expands the spectrum of intermestic relations to include the effect of foreign policy on domestic public opinion and the foreign policy impact of public opinion. Moreover, Logevall (2001) has further developed the concept of intermestic affairs to mean an international policy that affects or has implications on domestic discourse. Likewise, Bueno de Mesquita \& Smith (2012) argue that almost every critical dependent variable in the international arena, nowadays, is explored through the lens of domestic politics.[7], [8], [9]

Moreover, Putnam's (1988) "two-level games" theory explains that national leaders must win both a domestic political game and an international game during the foreign policymaking process, particularly on sensitive international issues with broad impact upon domestic constituents. Putnam (1988) also addressed the role of domestic preferences and coalitions, domestic political institutions and practices, the strategies and tactics of negotiators, uncertainty, the domestic reverberation of international pressures, and the interests of the chief negotiator. In other words, "two-level games" have added to the different foreign policy choices and international outcomes.[10]

International relations scholars highlight that the intermestic affairs concept has become increasingly predominant in the field of diplomatic history over the last decade (among others Logevall, 2009; Gienow-Hecht, 2009; Wolff and Wurm, 2011).[11],[12]. As such, international relations study focuses more on the role of domestic politics in international relations (Brenner \& Vanderbush, 2002; Foyle, 1997; Milner \& Tingley, 2015).[13], [14], 
[15]. Globalization has enhanced both the scope and depth of the interaction between domestic politics and foreign policy, making foreign policy an integral part of domestic politics.

In Indonesia context, as elaborated by Anwar (1994), it has been generally accepted that domestic factors largely determine the Indonesian foreign policy. Then, following the fall of Suharto's authoritarian government in 1998, Indonesia has sought to develop a more open democratic political environment. Henceforward, in the advent of Indonesia's post-Suharto political system, democratization has opened both the conduct of international relations and foreign policy-making to a larger number of actors who challenge the executive in the formulation of foreign policy interests and strategies (Anwar, 2010; Hill, 2003). [16], [17].

Similarly, studies on Indonesia's foreign policy and democratization have generally arrived at a similar conclusion; whereas democratization has led to a power shift from the executive to the legislature (Murphy, 2005), more complicated than Indonesia under Suharto (Laksmana, 2011), and increasing influences of non-governmental actors over foreign policymaking (Vermonte, 2005).[18], [19], [20]. Moreover, Gindarsah (2012) emphasized that domestic political forces have become the new power of influence to the executive government to change and even reverse the existing Indonesian foreign policy in order to pursue their respective societal aspirations and political ambitions.[21]

Specifically, Dosch (2006) elaborates that three essential areas have affected Indonesia's foreign policy based on the domestic changes: the process of foreign policy decision- making, the actors involved, and the issues. Dosch argues that a new democratic environment has opened up the foreign policy-making process and gives access to a larger number of 'new actors' to introduce specific ideas and agendas compared to under the authoritarian regime. In this research context, the halal issue is an emerging foreign policy agenda that was introduced by a new actor involved.[22]

\subsection{Technical Barrier to Trade (TBT)}

Indonesia was one of the founding countries of the World Trade Organization (WTO) by ratified Agreement establishing the World Trade Organization through Act number 7 the year 1994. Indonesia has also been involved in the negotiation of the General Agreement on Tariffs and Trade (GATT) since 24 February 1950. Since the WTO was established in 1995, GATT continues to serve as the basic set of trade rules agreed upon by nations.

The Agreement on Technical Barriers to Trade (TBT) is one of the most relevant international treaties of the WTO. It was negotiated during the Uruguay Round of the General Agreement on Tariffs and Trade and came into force at the end of 1994 with the creation of the WTO. The purpose ensures that technical negotiations and specifications, as well as testing and qualification procedures, are not defined.

The Technical Barriers to Trade (TBT) Agreement seeks to ensure that technical regulations, standards, and conformity assessment procedures are non-discriminatory and do not generate unnecessary drawbacks to trade. At the same time, it recognizes WTO members' right to implement measures to achieve legitimate policy objectives, such as the protection of human health and safety, or protection of the environment. In most common practice, TBT is the widely varying measures that countries use to regulate markets, preserve their consumers, or protect their natural resources (among other objectives). Nevertheless, they can also be used (or perceived by foreign countries) to discriminate against imports in order to protect domestic industries.

As stated on the preamble, the General Agreement on Tariffs and Trade (GATT) purpose was the "substantial reduction of tariffs and other trade barriers and the elimination of 
preferences, on a reciprocal and mutually advantageous basis." However, GATT Article XX on General Exceptions lays out a number of specific instances in which WTO members may be exempted from GATT rules, such as to protect public morals; to protect human, animal or plant life or health; and to the conservation of exhaustible natural resources. (GATT 1994:General Agreement on Tariffs and Trade 1994, Apr. 15, 1994, Marrakesh Agreement Establishing the World Trade Organization (1994))

Limental et al. (2018) elaborate that Indonesia could argue that a public morals exception exists to defend the Halal certification/labelling. It is not unusual that states invoke religious beliefs or public morals justification to restrict their imports, such as Israel prohibits the importation of non-kosher meat product, several countries put the ban on pornographic materials, Taiwan imposes the ban of the sale of dog meat, and the EU prohibits the importation of seal products. As such, it could be argued that Indonesia has the sovereign right to restrict trade for legitimate policy objectives. Considering the context of the Halal Act, public morals or protection of religious beliefs could be argued as the legitimate objective.

Concurrently, Ahamat \& Rahman (2018) depicts that derogation from the GATT/WTO norms in the name of halal can be justified on the ground of public morals because the latter concept may include the consideration of the religious. However, Indonesia utilizes the general exception under Article XX "to protect public morals" on Panel on Chicken Products (DS484) but not on Panel on Import Licences Regime (DS477) behind its import restrictions for halal-related reasons. [23].

\section{Method}

This study uses a qualitative approach by conducting literature reviews and e-interviews to gather information. Literature reviews were carried out on several previous studies on halal and halal certification issues. Besides, a review of policy and regulatory papers is also conducted, both at the national and international levels. Apart from Indonesia's Halal Product Assurance Act number 33 the year of 2014 (Halal Act) and its derivative regulations, the GATT regulations and Minutes of Meeting of WTO were also reviewed.

Interviews were conducted with some critical informants in several institutions. They are Halal Product Assurance Agency in the Ministry of Religious Affairs (BPJPH-MoRA), the Ministry of Trade, the Parliament Working Group of Halal Draft of Bill, and Indonesian representatives at five Indonesian Embassies in European countries, from the Government side. Information from five European countries is needed to find out how outsiders perceive the halal issue. The five countries (Germany, Poland, Austria, Switzerland and Denmark) are selected based on their unique characteristics. The Muslim community is a minority in their country, but the issue of halal is getting enough attention, such as with the existence of the Halal Centre. While for the non-Government side, they are the Assessment Institute for Foods, Drugs, and Cosmetics in the Indonesian Ulema Council (LPPOM-MUI), the Indonesian Halal Watch, Business sector (SwissCham), and Foreign Halal Certification Bodies in some European countries.

The data collection was conducted in July-September 2020 at the expense of the Center for Research and Development of Religious Life in the Indonesian Ministry of Religious Affairs. Due to pandemic and distance constraints, all eleven interviews were conducted online using the zoom application. The data were prominently analyzed using the intermestic approach introduced by Manning (1979). 


\section{Results and Discussion}

From the literature review and key informant interviews, this study collects some information that indicates the unclear certification process domestically in Indonesia which affects globally to international trade. Besides, the halal issue itself is seen as a barrier for several countries in terms of global trade. At the same time, the opportunities for international cooperation related to halal are constrained by the uniqueness of each country in perceiving and addressing the halal issue, which has religious dimensions. These findings will be explained in the following paragraphs.

Firstly, the obscurity of the halal certification process affecting international trade. The absence of the tariff provisions caused the stagnation of the certification process, which was followed by discretionary policies by the Ministry and bigger plans of Parliament for simplifying any rules on economic growth target through the omnibus law.

If we refer to the stages of the certification process in the Halal Product Guarantee Law, the process is quite clear. Business actors register an application for a halal certificate to BPJPH accompanied by a company profile, name and type of product, list of products and materials used, and description of the product processing process. Then, BPJPH determines the Halal Inspection Agency (LPH) to inspect the product. After examination and/or testing of a product's halalness by the Halal Auditor, LPH submits its results to BPJPH which are forwarded to Indonesian Ulema Council (MUI). Then, the determination of product halalness is performed in MUI Halal Fatwa Assembly. Finally, the Halal Certificate is issued and published by BPJPH.

However, in its implementation, the certification process according to the laws and regulations thereof cannot run seamlessly because there are no tariff provisions yet. Regarding tariffs, on the one hand, the government wants public services of halal certification to be low cost or flat rate so that it helps entrepreneurs and does not make an extra cost that will be borne by consumers. On the other hand, halal inspectors need quite expensive financial support to inspect each product.

Ruhana (2019) who studies the implementation of halal certification in Bogor City before and after mandatory, for instance, found various rates of halal certification. This condition makes entrepreneurs confused. He said:

“... Specifically related to the cost of certification, there are various experiences of business actors who have handled halal certification. This may depend on the level of difficulty or the number of products to be checked. LPPOM-MUI itself asks business actors to ask directly to the LPPOM-MUI treasurer via email by notifying the type, quantity and location of production. " [24]

In order to serve the public, the Minister of Religious Affairs issued a discretionary policy. Minister of Religious Affairs Decree No. 982 of 2019 was issued that, in essence, the certification process uses the previous tariff, and LPPOM MUI is asked to carry out the certification process - until the issuance of tariff provisions.

This condition was exacerbated by the process of drafting the Omnibus Law Bill by the Indonesian Parliament and the Government. In brief, this bill seeks to facilitate investment and boost economic growth by simplifying various regulations — including those related to the Halal Product Guarantee Law. The provisions regarding the stages of certification seek to be shortened and practical with this bill. Other matters are much debated, but until now it has not 
been decided so that the situation is still quite unclear. This condition makes both domestic and international companies, importer and exporters, constrained in their trading activities.

Secondly, the response of the international community to halal certificates is quite diverse, and some of them tend to be negative. For example, the issue of the Indonesia Halal Law was brought up at the WTO Sessions, and several countries paid particular attention to the halal issue concerning export-import activities.

\subsection{Indonesia's halal issue in WTO sessions}

Indonesia's halal law has been raised 13 times in specific trade concerns WTO sessions, by Australia, Brazil, New Zealand, United States of America, Canada, the European Union, and Taiwan. Those countries call Indonesia to reconsider its approach by keeping halal certification and labelling voluntary as well as the transparency of the halal law implementation.

In the WTO's Committee on Technical Barriers to Trade (TBT) in June 2016, the US delegation stressed the importance for Indonesian consumers of knowing whether products are halal and expressed its commitment to working with Indonesia to ensure that this objective would be achieved without creating any unnecessary barriers to trade. The representative of New Zealand noted that some issues in the derogative draft regulation of halal act remained unclear. While the European Union shared concerns raised by the US and New Zealand that the mandatory halal certification would imply significant additional costs for economic operators. The EU considered that the lack of transparency in implementing rules, and this fragmented approach created uncertainty. The representative of Australia urged Indonesia to comply with its international trade obligations and notify the Halal Act and related regulations to the WTO. ${ }^{1}$

In the WTO's Committee on TBT in November 2016, the US concerns that the halal requirements were cumbersome and duplicative. It was unclear what the registration requirements were for local products. The US and New Zealand requested that the draft implementing regulations of Halal Act be notified to the WTO prior to being finalized to allow time for comments from stakeholders and for those comments to be taken into account. The EU considered that the lack of transparency on implementing rules and the fragmented approach created uncertainty. Australia raised concerns regarding the possible trade restrictiveness of the proposed measures. Australia welcomed the delay in introducing the regulations until November 2019 and reminded Indonesia of their transparency obligations under the TBT Agreement. ${ }^{2}$

In the WTO's Committee on TBT in March 2017, the US and Australia again raised the issue on Indonesia halal law that international private sectors (and Indonesian) expressed concern that the mandatory labelling requirements could significantly restrict access to current and future products. This measure could also impose significant burdens on both international and Indonesian SMEs and disrupt Indonesian manufacturing and exports. The EU reiterated severe concerns that were not allowing non-halal certified products would amount to a total ban on the importation of non-halal products. EU reminds Indonesia that under WTO rules, measures should not be trade-restrictive and that the non-discrimination principle should be taken into account, as well as transparency provisions. By keeping halal certification and labelling voluntary, this would be less trade-restrictive and more in line with TBT objectives.

\footnotetext{
${ }^{1}$ WTO, G/TBT/M/69, 15 June 2016, paras. 3.321-3.327

${ }^{2}$ WTO, G/TBT/M/70, 10 November 2016, paras. 2.259-2.264
} 
The EU requested further information and the intended timeline on the draft government decree (Rancangan Peraturan Pemerintah, RPP) and that Indonesia notifies any subsequent implementing rules while still in draft form to the WTO. ${ }^{3}$

Since Indonesia has not updated concerns raised in WTO's Committee on TBT on June and November 2017, the US, EU, Australia, Brazil, and Canada repeated concerns raised in previous TBT Committee meetings by stating profound impact Indonesia's halal law on international trade. Disappointment to Indonesia began to rise in WTO's Committee on TBT in March 2018 and June 2018. The US, EU, Australia, and Brazil reiterated previously raised serious concerns in the transparency regarding the draft regulations and sufficient transition time. $^{4}$

Response to the displeasure rise in the Committee, Indonesia provided the same responses as the previous Committee meetings that the Member Countries raised concerns being discussed among related government institutions. Indonesia also explained that as a new institution that was formed towards the end of 2017, the Agency of Halal Product Assurance (BPJPH) would need adjustment, cooperation, and coordination to ensure effective implementation of the law, including implementing arrangement with all stakeholders at the central and regional level. Indonesia further ensures that the regulation would be in line with the TBT Agreement.

In WTO's Committee on TBT on November 2018, despite the continued concerns from the same member countries (the US, Australia, Brazil, and the UE), Indonesia sent a bold message that as the WTO Member with the largest Muslim population, Indonesia needed to ensure the information on products circulated in the market was sufficient for assuring halal integrity. Hence, the necessity to ensure the differentiation of halal and non-halal products to appease concerns from domestic stakeholders. By providing non-halal information in the form of pictures, marks and/or a statement, it would take into account protection and human rights of vulnerable groups, particularly disabled people. Indonesia also updated the Mutual Recognition Arrangements (MRAs) for a halal certification scheme for consideration in product acceptance. The US praised Indonesia for extending the recognition of foreign halal certification bodies so that halal-certified agricultural products entering Indonesia could continue uninterrupted during the transition time and with implementation regulations still pending finalization. ${ }^{5}$

In the WTO's Committee on TBT in March and June 2019, the same concern was raised by the WTO member countries (the US, Australia, Brazil, New Zealand, and the UE). In March 2019, Australia encouraged Indonesia to establish an open dialogue with trading partners to ensure foreign businesses and their valued Indonesian importers remained adequately informed of new requirements under the Halal Law. ${ }^{6}$ Further in June 2019, Australia thanked Indonesia for including Australia in the recent Halal Law socialization event held by the Japanese External Trade Organization. However, Australia was disappointed that Indonesia had not circulated the final draft to trading partners for comment before finalization, given the broad scope and potential impact on traded commodities and services. Australia encouraged Indonesia to ensure an open dialogue with trading partners to allow foreign businesses and their valued Indonesian importers to remain adequately informed of new requirements under the Halal Law. ${ }^{7}$

\footnotetext{
${ }^{3}$ WTO, G/TBT/M/71, 29 March 2017, paras. 2.204-2.211

${ }^{4}$ WTO, G/TBT/M/72, 14 June 2017, paras. 3.167-3.171

${ }^{5}$ WTO, G/TBT/M/76, 14 November 2018, paras. 3.107-3.115

${ }^{6}$ WTO, G/TBT/M/77, 6 March 2019, paras. 3.102-3.109

${ }^{7}$ WTO, G/TBT/M/78, 20 June 2019, paras. 3.163-3.172
} 
During the WTO's Committee on TBT on March and June 2019, Indonesia responded eloquently by elaborating Mutual Recognition Arrangements (MRAs) for the halal certification scheme to reduce any unnecessary technical barrier. Indonesia was fully committed to applying the principles of mutual recognition, and acceptance of the certification process carried out by certification bodies outside Indonesia with the proviso that the certification bodies outside Indonesia were either accredited by accreditation bodies with an MRA with KAN (Indonesia Accreditation Body) or had signed mutual acceptance cooperation with the Indonesian government based on mutual reciprocity principles. Products containing non-halal ingredients could still circulate, enter, and trade in Indonesia by including non-halal information complying with the regulation of the National Agency for Drug and Food Control. Indonesia assured the Committee that the implementation of the law would not limit people's freedom to choose their desired products.

WTO's Committee on TBT on November 2019 marked a critical moment in halal discussion in the WTO since it was established a month after Indonesia's Halal Act had entered into force on 17 October 2019 and was participated by the Head of BPJPH. Taiwan joined the USA, Australia, Brazil, New Zealand, Canada, and the EU to raise concern on Indonesia's halal law. ${ }^{8}$

Canada reviewed the certification and recognition process of foreign halal certifying organizations, were lacking and remained unclear. Canada and Australia encouraged Indonesia to consult and provide timely information to trading partners to ensure that measures did not unduly restrict trade.

While Taiwan asked Indonesia to explain: certification procedures; procedures for the mutual recognition for foreign halal certification bodies; differences between previous specifications and new ones; and, whether the current foreign institutions that had been approved were required to be reapproved by the BPJPH, similarly, New Zealand and Brazil sought clarification on the scope of the term "non-halal products" and how labelling requirements would be managed. New Zealand also thanked Indonesia for notified WTO of the draft of the Minister of Religious Affairs regarding The Implementation of Halal Product Assurance (Rancangan Peraturan Menteri Agama tentang Penyelenggaraan Jaminan Produk Halal).

Under the WTO regulations, member countries proposed to notify the regulation draft related to international trade. On 14 October 2019, Indonesia notified the draft of implementing regulation by the Minister of Religious Affairs arranged the halal assurance system as follows: (i) product scope; (ii) transition period and imposed time that is adjusted to the scope of the products; (iii) inclusion of labelling for halal and information on non-halal products; (iv) halal conformity assessment system and its mutual recognition arrangement; (v) registration provision for a halal certificate; and, (vi) the mechanism of halal-certified products during the transition period.

Other than Indonesia's Halal Act 13/2014, Indonesia's halal assurance system also part as issues raised in specific trade concern WTO sessions on Regulation of the Minister of Agriculture Indonesia concerning Importation of Carcass, Meat and/or Processed Meat Products between March 2015 and June 2016 (four sessions).

Indonesia's halal assurance system was also scrutinized during Indonesia - Measures Concerning the Importation of Chicken Meat and Chicken Products (DS484) complaint by Brazil. In this case, Brazil alleged that some of Indonesia's prohibitions on the importation of chicken meat and chicken products from Brazil were inconsistent with GATT/WTO rules.

${ }^{8}$ WTO, G/TBT/M/79, 13 November 2019, paras. 2.75-2.81 
Some of the import prohibitions were contained in the different regulations taken by Indonesia on halal slaughtering and labelling requirements for imported chicken meat and chicken products. More specifically, the regulations govern the surveillance and implementation of halal slaughtering and labelling requirements whose problem lies in the claim by Brazil that surveillance and implementation of requirements for imported chicken products were stricter than those applied to domestic production in Indonesia.

Ahamat \& Rahman (2018) argued that Indonesia - Chicken Products shows that the existence of halal measures is recognized on the WTO plane. As a result, Indonesia renewed the import regulation of poultry and its products (Regulation of Ministry of Agriculture and Ministry of Trade). Nevertheless, the Panel found that Indonesia did not discriminate against imported chicken in enforcing its halal labelling requirements.

\subsection{The European Concern to Indonesia's Halal Law}

To series of interviews, this study finds that Indonesia's halal law not only ignites the dynamic in WTO sessions and panels but also increases various concerns from businesses in importing countries in Europe. At the Joint Economic and Trade Commission (JETC) meeting between Indonesia and Switzerland on 15 July 2019, businesses in European countries understand Indonesia's authority to ensure the availability of halal products in the Muslimmajority countries. However, they required transparency and clear information for halal certification procedures under the Halal Law regime. The Swiss business association in Indonesia, SwissCham, raised questions regarding the halal regulation in Indonesia tighter than in Saudi Arabia, Malaysia and other Muslim majority countries. For this reason, SwissCham asked the Indonesian government to open as wide a channel of communication as possible to address business-related concerns in halal certification.

Other than international trade issues, Indonesia's Halal Act also promotes international cooperation and mutual recognition agreement. This study finds that international cooperation on halal matters face concerns from the European countries questionably since they do not have a government agency on religious matters.

Interestingly, all research object countries see the issue of halal not as a religious issue per se. Most European countries view the halal issue as an international trade issue, such as Poland (under the Ministry of Economic Development), Austria (under Ministry of Digital and Economy), and Switzerland (Secretariat of Economic Cooperation SECO). Meanwhile, Denmark sees the halal issue as more of the issue of animal welfare and handled by the "hybrid" Public-Private Partnership (PPP), namely the Danish Agriculture and Food Council (DAFC). Hence, the halal industry could arguably provoke the institutional arrangement in European countries for various reasons.

Moreover, the Indonesian Embassy in Warsaw and Vienna welcomes the BPJPH plan and sees an opportunity to develop cooperation on capacity building and technical assistance in the halal industry in Poland and Austria. Correspondingly, the Indonesian Embassy in Berlin and Vienna suggested that mutual recognition agreement on halal matters approach not bilaterally but through the European Union as a customs union. BPJPH suggested considering a demarche to the EU to explain clearly and comprehensively on Indonesia's halal assurance system. 


\section{Conclusion}

To sum up, the research shows that Indonesia's Halal Law has a significant intermestic factor by showing interrelationship influence between domestic and international dynamics. It is indicated by the lack of clarity of Indonesia's halal certification process (e.g. in the absence of tariff regulation or lack of dissemination) immensely affects international trade and businesses in many countries. At the same time, the deliberation on WTO sessions and dispute settlement panel depicts that severe international concern on Indonesia's halal certification, even some measures show a desire to alter Indonesia's halal law.

The enactment of halal law expands halal as a religious term into an international trade instrument. Therefore, the halal matters need to be approached by a broader aspect, such as diplomacy, political economy, or international trade studies.

In this borderless world, the intermestic factors of halal certification need to be realized by domestic policy-makers. So that the halal guarantee products and certification could win "two-level games" both a domestic and an international political game. 


\section{References}

[1] Mulyono, Agus, et al,: Kajian aktual isu halal. Jakarta: Litbangdiklat Press. (2018)

[2] Limenta, M., Edis, B. M., \& Fernando, O.: Disabling labelling in Indonesia: invoking WTO laws in the wake of halal policy objectives. World Trade Review, 17(3), 451-476. (2018).

[3] Amaliah, L. H.: Menata jaminan halal di Indonesia. Jakarta: Beeboks Publishing. (2016).

[4] Rosenau, J. N.: International politics and foreign policy : a reader in research and theory (Rev. ed.. ed.): New York : The Free Press, London : Collier-Macmillan. (1969).

[5] Wolff, J., \& Wurm, I.: Towards a theory of external democracy promotion: A proposal for theoretical classification. Security Dialogue, 42(1), 77-96. (2011).

[6] Maning, B.: The congress, the executive, and intermestic affairs. Foreign Affairs, 57, 308. (1979).

[7] Barilleaux, R. J.: The President," Intermestic" Issues, and the Risks of Policy Leadership. Presidential Studies Quarterly, 754-767. (1985).

[8] Logevall, F.: Choosing war: the lost chance for peace and the escalation of war in Vietnam. Univ of California Press. (2001).

[9] Bueno de Mesquita, B., \& Smith, A.: Domestic explanations of international relations. Annual R eview of Political Science, 15, 161-181. (2012).

[10] Putnam, R. D.: Diplomacy and domestic politics. The logic of the two-level games. International Organization, 42(3), 1. (1993).

[11] Logevall, F.: Politics and foreign relations. Journal of American History, 95(4), 1074-1078. (2009).

[12] Gienow-Hecht, J. C.: What bandwagon? diplomatic history today. Journal of American History, 95(4), 1083-1086. (2009).

[13] Brenner, P., Haney, P. J., \& Vanderbush, W.: The confluence of domestic and international interests: US policy toward Cuba, 1998-2001. International Studies Perspectives, 3(2), 192-208. (2002).

[14] Foyle, D. C.: Public opinion and foreign policy: elite beliefs as a mediating variable. International Studies Quarterly, 41(1), 141-169. (1997).

[15] Milner, H. V., \& Tingley, D.: Sailing the water's edge: The domestic politics of American foreign policy. Princeton University Press. (2015).

[16] Anwar, D. F.: Indonesia in ASEAN: foreign policy and regionalism: Singapore : Institute of Southeast Asian Studies. (1994).

[17] Anwar, D. F.: The impact of domestic and asian regional changes on indonesian foreign policy. Southeast Asian Affairs, 2010(1), 126-141. doi:10.1355/SEAA10H(2010).

[18] Murphy, A. M.: Indonesia and the world. In J. Bresnan (Ed.), Indonesia: The Great Transition (pp. 239-295): Oxford: Rowman \& Littlefield. (2005).

[19] Laksmana, E. A.: Indonesia's rising regional and global profile: does size really matter? Contemporary Southeast Asia, 33(2), 157-182. (2011).

[20] Vermonte, P. J.: Demokratisasi dan politik luar negeri indonesia: membangun citra diri. In B. Bandoro (Ed.), Mencari desain baru politik luar negeri Indonesia (pp. 37-39). Jakarta: CSIS. (2005).

[21] Gindarsah, I.: Democracy and foreign policy-making in Indonesia: a case study of the Iranian Nuclear Issue, 2007-08. Contemporary Southeast Asia: A Journal of International and Strategic Affairs, 34(3), 416-437. (2012).

[22] Dosch, J.: The impact of democratization on the making of foreign policy in Indonesia, Thailand and the Philippines. Südostasien aktuell: journal of current Southeast Asian affairs, 25(5), 42-70. (2006).

[23] Ahamat, H., \& Rahman, N. A.: Halal food, market access and exception to wto law: new aspects learned from indonesia-chicken products. Asian J. WTO \& Int' 1 Health L \& Pol'y, 13, 355. (2018).

[24] Ruhana, Akmal Salim, Aam Slamet Rusydiana.: Implementasi sertifikasi halal di daerah pra dan pasca penerapan mandatory halal: studi di kota Bogor, in mandatory halal: efektivitas pelayanan publik vs kepatuhan hukum, Jakarta: Puslitbang Bimas Agama Kemenag RI, 2019(2019). 